1998

\title{
The Constitutionalization of Law in the United States
}

Richard Kay

William B. Fisch

Follow this and additional works at: https://opencommons.uconn.edu/law_papers

Part of the Constitutional Law Commons

\section{Recommended Citation}

Kay, Richard and Fisch, William B., "The Constitutionalization of Law in the United States" (1998). Faculty Articles and Papers. 512.

https://opencommons.uconn.edu/law_papers/512 


\section{WILLIAM B. FISCH \& RICHARD S. KAY}

\section{The Constitutionalization of Law in the United States}

\section{The Constitution as Supreme Law}

The United States may be the prime example of constitutionalization of the legal order. It was the first system (though no longer the only one) to make its written constitution directly applicable law, superior to all other sources of law, in all courts. ${ }^{1}$ A corollary to this legalization of the constitution is that the federal courts and a majority of state court systems will only entertain a constitutional claim in the context of a concrete dispute involving adversary parties with a specific stake in the outcome, and abstract review in these systems is unknown. ${ }^{2}$

The text of the federal constitution itself has a terse and broadly formulated style, established in the original document and the earliest amendments and maintained to the present day, making interpretation both indispensable and difficult. On the other hand there are no "constitutional judges," in the sense of specialists in constitutional law; all the judges who decide constitutional cases spend most of their time deciding cases arising under ordinary laws and, perhaps more importantly, so-called "common [i.e., judge-made] law." The limited capacity of the U.S. Supreme Court, with only 9 justices deciding only en banc, leaves room for local and regional differences in the working constitutional law administered by state and lower federal courts. The system of constitutional adjudication, therefore including the Supreme Court itself - is exposed to and has accommodated a wide spectrum of interpretive approaches. ${ }^{3}$ As a result of these and other factors, the United States is also a paradigm case for

WiLliam B. FisCh is Isidor Loeb Professor of Law, University of Missouri-Columbia. RICHARD S. KAY is William J. Brennan Professor of Law, University of Connecticut. This is an abridged version of the United States report on the topic "The Constitutionalization of the Legal Order," presented at the XV ${ }^{\text {th }}$ International Congress of Comparative Law, July 26-August 1, 1998.

1. On the process whereby this became established, see Fisch \& Kay, "The Legitimacy of the Constitutional Judge and Theories of Interpretation in the United States," 42 Am. J. Comp. L. (Supp.) 517, 518-19 (1994).

2. See Fisch \& Kay, supra n. 1 , at $517 \mathrm{ff}$.

3. On interpretive theories in American constitutional adjudication, see Fisch \& Kay, supra n. 1. 
the equation of constitutionalization with judicialization: heavy reliance on courts to decide the most fundamental issues of law.

In this paper we try to illustrate the process by some of the most prominent examples of constitutionalization in terms of their impact on the legal as well as social and political life of the country.

\section{The Enlargement of Constitutional Law}

\section{A. The Development of New Constitutional Rules}

The constitutionalization of law in the United States has steadily, if not continuously, increased over its history, most obviously by expanding the content and scope of the rules of the constitution to regulate larger categories of conduct. Under the federal constitution three mechanisms are available: amendment of the text, legislative implementation by Congress, and judicial interpretation. A few prominent examples will serve to illustrate the overwhelming role of the courts in bringing new rules to life.

\section{Amendment of the Constitution}

Because of the difficulty of the amendment process prescribed in Art. V, it has succeeded only 17 times since the more or less contemporaneous adoption of the Bill of Rights in 1791. The amendments have had, to be sure, an enormous effect on the legal, social and political life of the nation, but largely through the medium of judicial interpretation and legislative enforcement. ${ }^{4}$

Undoubtedly the most influential of these amendments for the modern legal order has been the $14^{\text {th }}$ (itself the product of a rather questionable process in 1868$)^{5}$, which eventually became the vehicle for applying major individual rights protections specifically to the states. The Supreme Court's initial interpretation of the two key clauses of that amendment, however, was quite narrow despite the breadth and generality of their language: ${ }^{6}$ the Equal Protection clause was held to be intended exclusively for the benefit of the former slave race, and the Due Process clause was held to be an exclu-

4. The relatively few Supreme Court decisions on the amendment process itself have left Congress in charge of the process, while the role of the courts is to confirm and enforce its decisions; the constitutionality of amendment-process decisions by Congress, for example in determining whether or not a particular amendment has been adopted, is probably not justiciable. See, e.g., John E. Nowak \& Ronald D. Rotunda, Constitutional Law 111-13 (5 $5^{\text {th }}$ ed. 1995).

5. See the description in Coleman v. Miller, 307 U.S. 433, 448 (1939); Erwin Chermerinsky, Constitutional Law: Principles and Policies 14 (1997).

6. $14^{\text {th }}$ Amendment $\$ 1$ : “. . .nor shall any State deprive any person of life, liberty, or property, without due process of law; nor deny to any person within its jurisdiction the equal protection of the laws." 
sively procedural provision. ${ }^{7}$ Not until a quarter-century later did the Court begin to find in the $14^{\text {th }}$ Amendment's due process clause a generalized substantive protection against undue interference by the states with individual liberty ${ }^{8}$ (on which more below), and in the equal protection clause a generalized protection against arbitrary classifications. ${ }^{9}$ Both of these linguistically plausible but historically controversial interpretations have experienced much expansion and contraction in subsequent years, generating an enormous volume of litigation and debate over the proper meaning of the clauses. Four of the subsequent amendments have given more specific expression to the general concept of equal protection, but all of those have dealt with voting rights ${ }^{10}$ and have had only indirect influence over the course of interpretation of the more general clause. ${ }^{11}$

\section{Congressional Power to Enforce Constitutional Protections}

A number of the amendments, including the $14^{\text {th }}$, explicitly give to Congress the power to enforce their provisions "by appropriate legislation."12 Vast statutory and administrative structures have been erected pursuant to these powers, especially under numerous Civil Rights and Voting Rights Acts, each with its own very considerable capacity for generating lawsuits and administrative proceedings. Some of these statutes have prohibited state conduct which would not in and of itself constitute a violation of the constitutional provision in question as judicially interpreted, thus raising the question whether the enforcement power gives Congress an independent interpretive power. At least two decisions of the Court seemed to give an affirmative answer in sustaining such prohibitions, ${ }^{13}$ while others strongly suggested that what Congress was properly doing was merely fashioning a remedy for past conduct which itself constituted a violation of the constitution as interpreted by the courts. ${ }^{14}$

The claim of an independent congressional interpretive power under the enforcement clauses has now been firmly rejected, how-

7. The Slaughterhouse Cases, 83 U.S. (16 Wall.) 36 (1873).

8. Lochner v. New York, 198 U.S. 45 (1905), following up on extensive and explicit dicta in Allgeyer v. Louisiana, 165 U.S. 578 (1897) (itself a case which procedural limitations were in fact sufficient to decide).

9. Gulf, Colorado \& Santa Fe Railroad Co. v. Ellis, 165 U.S. 150 (1897).

10. The $15^{\text {th }}$ (racial discrimination); the $19^{\text {th }}$ (sex discrimination); the $24^{\text {th }}$ (poll taxes); and the $26^{\text {th }}$ (age discrimination, over the age of 18 ).

11. Harper v. Virginia State Board of Elections, 383 U.S. 663 (1966), relied in part upon the $24^{\text {th }}$ Amendment's prohibition against poll taxes in federal elections, to find that the equal protection clause prohibits such taxes in state elections as well.

12. $13^{\text {th }}$ Amendment prohibiting slavery, $\S 2 ; 14^{\text {th }}, \S 5$; each of the voting rights amendments cited supra n. 10.

13. Katzenbach v. Morgan, 384 U.S. 641 (1966); City of Rome v. United States, 446 U.S. 156 (1980).

14. South Carolina v. Katzenbach, 383 U.S. 301 (1966); Oregon v. Mitchell, 400 U.S. 112 (1970). 
ever, in City of Boerne v. Flores. ${ }^{15}$ Seven years earlier, in Employment Division v. Smith, ${ }^{16}$ the Court had held that a state law did not violate the First Amendment's protection for the free exercise of religion, merely because its application to a particular case imposed a substantial burden on the addressee's religious practices, so long as the law is of general application and its enforcement in the particular case did not have an antireligious purpose. This had in effect overruled prior decisions which had required a state to show a compelling justification for enforcing its laws when they impose a substantial burden on a person's religious beliefs or practices. ${ }^{17}$ Congress responded to Smith by enacting the Religious Freedom Restoration Act, ${ }^{18}$ explicitly making the "substantial burden" test applicable to all government action and relying on $14^{\text {th }}$ Amendment enforcement powers in applying that test to state and local government. In City of Boerne the Court held the Act invalid, insisting that Congress has no power under the enforcement clauses to impose its own interpretation of the constitution upon the courts. ${ }^{19}$ Thus the Court is firmly committed to judicial supremacy in constitutional interpretation.

\section{New Constitutional Rules Through Judicial Interpretation}

Among the most controversial of the Supreme Court's interpretive moves has been the discovery of a substantive dimension in the "due process" clauses of the $5^{\text {th }}$ and $14^{\text {th }}$ Amendments. The first branch of this line of reasoning involved state regulation of economic interests. It reached full statement in 1905 as a general requirement of reasonableness, ${ }^{20}$ under which the courts passed on a case by case basis on the perceived fairness and effectiveness of numerous instances of economic regulation. This kind of review was effectively abandoned by 1937, in favor of a much more deferential approach whereby any regulation will be upheld unless it is arbitrary to the point of irrationality. ${ }^{21}$

15. U.S. _, 117 S.Ct. 2157 (1997).

16. $\overline{494}$ U.S. $\overline{872}(1990)$.

17. The leading modern case, articulating the "substantial burden" test for the first time, was Sherbert v. Verner, 374 U.S. 398 (1963). In Smith, the majority reverted to one of the earliest of the Free Exercise cases, Reynolds v. United States, 98 U.S. 145 (1878), which sustained the application of federal bigamy laws against Mormons whose practice of polygamy was religiously commanded, on the ground that the clause only forbade the government to prohibit a religious belief, and left it free to prohibit actions regardless of their motivation.

18. 107 Stat. 1488,42 U.S.C. $\$ 2000$ b et seq.

19. The dissenters would have overruled Smith, but did not disagree on Congress' power, see 117 S.Ct. at 2176 (O'Connor, J., dissenting).

20. Lochner v. New York, supra n. 8, striking down a state law limiting the number of hours per day that bakery workers were allowed to work, ostensibly for health reasons, as a violation of "freedom of contract". On the pre-Lochner history of this concept see, e.g., Chermerinsky, supra n. 5, at 474-79.

21. West Coast Hotel Co. v. Parrish, 300 U.S. 379 (1937). 
The second branch protects fundamental personal rights. It began to take hold in the 1920's with two decisions striking down state laws forbidding the teaching of foreign languages to primary-school children ${ }^{22}$ and requiring children to attend public school, ${ }^{23}$ respectively. These cases defined "liberty" as including, in addition to the economic rights already mentioned, the rights "to acquire useful knowledge, to marry, establish a home and bring up children, to worship God according to the dictates of his own conscience, and generally to enjoy those privileges long recognized at common law as essential to the orderly pursuit of happiness by free men." ${ }^{24}$

This fundamental-rights jurisprudence received a dramatic impetus in 1965 with the discovery of a "right of privacy," in Griswold $v$. Connecticut. ${ }^{25}$ That decision struck down a state law prohibiting the use or advising the use of contraceptives even by married couples. The principal opinion by Justice Douglas drew upon Pierce, Meyer, and other precedents as well as analogies to specific rights enumerated in the $3^{\text {rd }}, 4^{\text {th }}$ and $5^{\text {th }}$ Amendments, and the apparent warrant in the $9^{\text {th }}$ Amendment for protection of unenumerated rights, to find protection for the "intimate relation of husband and wife" as a "zone of privacy." This was soon extended to unmarried persons, on the premise that the right attaches not to relationships but to individuals making fundamental personal decisions. ${ }^{26}$

The contraception cases stimulated much discussion and criticism of their logic and interpretive technique, ${ }^{27}$ without generating much sympathy for what even a dissenter in Griswold called an "uncommonly silly law."28 The extension of the concept to a more general right of personal autonomy, however, largely invalidating state anti-abortion laws, ${ }^{29}$ plunged the Court into the heart of a highly charged, hotly contested moral and social debate from which it has yet to extricate itself. The Court attempted to reconcile a right inferred from this newly formulated and not yet fully accepted body of higher law with the state's compelling interests in protecting the health of the mother and the life of a viable fetus. In so doing it put its own legitimacy into issue, even in the eyes of some of the staunchest defenders of its previous civil-rights activism. ${ }^{30}$ In dozens

22. Meyer v. Nebraska, 262 U.S. 390 (1923).

23. Pierce v. Society of Sisters, 268 U.S. 510 (1925).

24. Meyer, 262 U.S. at 399.

25. 381 U.S. 479 (1965).

26. Eisenstadt v. Baird, 405 U.S. 438 (1972).

27. See, e.g., "Symposium on the Griswold Case and the Right of Privacy," 64 Mich. L. Rev. $197 \mathrm{ff}$. (1965); Franklin, "The Ninth Amendment as Civil Law Method and Its Implications for a Republican Form of Government," 40 Tulane L. Rev. 487 (1966).

28. 381 U.S. at 527 (Stewart, J., dissenting).

29. Roe v. Wade, 410 U.S. 113 (1973).

30. See Ely, "The Wages of Crying Wolf: A Comment on Roe v. Wade," 82 Yale L.J. 920 (1973); id., Democracy and Distrust passim (1980). 
of subsequent decisions the Court has passed on many variations in the regulation of abortions, qualifying and narrowing but not quite abandoning the constitutional right. It has upheld legislation aimed at maintaining safe medical practices and has allowed an outright prohibition of abortion after the fetus has reached viability (except to preserve the life of the mother). ${ }^{31}$ It has ruled that governments are not required to provide public funds or facilities for abortions even when they do so for other medical procedures, ${ }^{32}$ and that a state may establish informed consent procedures for abortions designed to persuade the mother to choose other options, so long as it does not thereby impose an "undue burden" on the woman's ultimate choice. ${ }^{33}$ Each of these decisions, it is safe to say, provides an opening for further efforts on the part of legislators to circumscribe the right, which in turn must be judicially evaluated.

This jurisprudence of unenumerated fundamental personal rights has had a number of other ramifications for government regulation. With respect to the regulation of sexual mores, the Court has held that a state may forbid specific homosexual acts such as sodomy, ${ }^{34}$ but (in a very recent decision fraught with conceptual difficulty) that under the equal protection clause a state may not single out homosexuals in its own constitution for special political disadvantage by forbidding state and local governments from adopting laws or regulations protecting them against discrimination. ${ }^{35}$ With respect to local zoning laws designed to regulate the types of uses to which land and buildings may be put, the Court held that a city may not define "single family occupancy" in such a way as to prevent persons related by blood from living together, ${ }^{36}$ though it can prohibit unrelated persons from living together as a "single family." ${ }^{7}$ In devising ways to enforce a non-custodial parent's obligation to support his child, the state may not make it a condition of his right to marry that he persuade a judge, in effect, that the marriage will not impair his ability to comply with the support obligation. ${ }^{38}$

These decisions provide only the most currently controversial example of the capacity of the courts, through expansive interpretation of the open-ended provisions of the Constitution, dramatically to

31. E.g., Planned Parenthood of Central Missouri v. Danforth, 428 U.S. 52 (1976).

32. Webster v. Reproductive Health Services, 492 U.S. 490 (1989), confirming numerous earlier decisions in this respect.

33. Planned Parenthood of Southern Pennsylvania v. Casey, 505 U.S. 833 (1992).

34. Bowers v. Hardwick, 478 U.S. 186 (1986).

35. Romer v. Evans, 517 U.S. 620 , 116 S.Ct. 1620, 134 L.Ed.2d 855 (1996). For critical commentary see, e.g., Seidman, "Romer's Radicalism: The Unexpected Revival of Warren Court Activism," 1996 S. Ct. Rev. 67.

36. Moore v. City of East Cleveland, Ohio, 431 U.S. 494 (1977) (invalidating an ordinance which forbade a grandmother, her son and two grandchildren from living together because one of the grandchildren was the other's cousin rather than sibling).

37. Village of Belle Terre v. Boraas, 416 U.S. 1 (1974).

38. Zablocki v. Redhail, 434 U.S. 374 (1978). 
transform existing regimes of law for large categories of human conduct. Matters of family life and sexual relations, traditionally a province of state and local regulation, are now to a very significant degree governed by standards developed in the course of constitutional adjudication - the law in this area, in short, has been constitutionalized.

\section{B. The Impact of Constitutional Federalism}

The Constitution defines the powers of the federal government and implicitly leaves every other subject of public authority to the states. This allocation arose not merely from political bargaining at the time of the founding, but also from a judgment on the quality of the law that might be expected to result. ${ }^{39}$ Consequently, the constitutional division of authority is reflected, to some extent, in the content of every instance of legislation, state or federal. However, the textual categories of federal and state legislative authority are far from precise. Judicial decisions interpreting and reinterpreting these provisions, therefore, not only decide the fate of the particular laws in dispute but also profoundly influence the shape and content of subsequent laws.

This is manifestly true of federal law. Early in American constitutional history the Supreme Court refused to adopt an interpretation confining the grants of power to Congress to the literal subjects specified. ${ }^{40}$ Chief Justice Marshall reasoned that the constitutional powers established must be liberally construed in light of the constitutional design to provide for numerous and varied objectives to be pursued over an indefinite period of time in the face of the inevitably "various crises of human affairs." The powers of Congress were, to be sure, limited to those enumerated in the Constitution but any measure "appropriate" and "plainly adapted" to a constitutional end would be permitted. While Marshall's generous view appeared to prevail for most of the nineteenth century, a considerably more energetic assertion of constitutional limits developed at the end of the century and, with it, a series of judicial doctrines seeking to define those limits. Thus federal statutes were subject to review to determine whether the object of regulation had a direct (constitutional) or merely indirect (unconstitutional) effect on interstate commerce, whether a regulated event was a single matter entirely within a state (unconstitutional) or part of an interstate commercial chain (constitutional), and whether a tax was a genuine attempt to raise revenue (constitutional) or an effective regulation of health, welfare or morals

39. See Hamilton, The Federalist No. 17 (Clinton Rossiter, ed. 1961). Cf. McCulloch v. Maryland, 17 U.S. (4 Wheat.) 316, 431 (1819). See also Bermann, “Taking Subsidiarity Seriously: Federalism in the European Community and the United States," 94 Colum. L. Rev. 331, 405 (1994) (discussing virtues attributed to localism).

40. McCulloch v. Maryland, supra n. 39. 
(unconstitutional). ${ }^{41}$ This kind of scrutiny necessarily imparted a critical constitutional dimension to both the process of legislation and the reaction to such legislation from those affected by it.

By the middle of this century, however, the Supreme Court began to construe the sphere of federal legislative jurisdiction with such deference to Congressional judgment that the effective result appeared to be an unlimited field for federal regulation. It upheld federal legislation which only a truly liberal imagination could find encompassed within the constitutional enumeration of Congressional powers, legislation plainly, and often explicitly, intended to deal, on a national basis, with matters previously understood as the exclusive domain of the states. ${ }^{42}$

While the propriety of the judicial confirmation of such broad federal authority may be (and has been) doubted, ${ }^{43}$ its effect on the subject of this report was to minimize the constitutionalization of federal law. Once a more or less free license was granted the Congress, it could act without reference to constitutional rules or doctrines, textual or judicial, concerning the federal division of powers. Now, however, there are signs that the Supreme Court may be again taking a more rigorous approach to federal limitations. In its 1995 judgment in United States v. Lopez $z^{44}$ it held unconstitutional a federal statute making criminal the possession of a firearm in a school zone. Here the Court reaffirmed that the test for the validity of a federal measure, premised on its granted power to regulate commerce among the states, was whether the regulated activity "substantially affects interstate commerce." The Court did little to elaborate the test, finding in the instant case simply that the law "has nothing to with 'commerce' or any sort of economic enterprise, however broadly one might define those terms." 45

Lopez thus raises the possibility that federal law must again conform to some judicially specified definition of the appropriate arena for federal action. Equally significantly, that definition may not be fixed but will unfold in the process of constitutional litigation. The

41. Carter v. Carter Coal Co., 298 U.S. 238, 307-08 (1936) (direct v. indirect), A.L.A. Schecter Poultry Corp. v. United States, 295 U.S. 495, 542-44 (1935) (entirely within a state); Stafford v. Wallace, 258 U.S. 495, 519 (1922) (within a commercial chain); Bailey v. Drexel Furniture Co., 259 U.S. 20, 37-39 (1922) (tax as effective regulation).

42. See, e.g., Perez v. United States, 402 U.S. 146, 149-57 (1971)(loan sharking); United States v. Darby, 312 U.S. 100, 115-22 (1941)(wages and hours); Heart of Atlanta Motel, Inc. v. United States, 379 U.S. 241, 249-58 (1964)(private racial discrimination).

43. On the practices of American constitutional interpretation and the academic responses to those practices see generally Fisch \& Kay, supra n. 1 .

44. 514 U.S. 549, 552-68 (1995). See also Printz v. United States, 65 U.S.L.W. 4731 (June 24, 1997)(States may not be required to administer federal legislative programs,)

45. Id. at 559,561 . 
opinion of the court conceded that its approach might "in some cases result in legal uncertainty." 46 That is, the content of federal law will, in an important sense, be the product, not of legislative policy, but of the changing interpretation and application of constitutional norms. The Court rooted this constitutionalization of law in the original determination to treat the Constitution as binding law and the recognition of the Supreme Court as the ultimate interpreter of that law: "Congress has operated within this framework of legal uncertainty ever since this Court determined that it was the judiciary's duty to say what the law is." 47

The Constitution's allocation of authority between the states and the national government also influences the law of the states. Certain grants of legislative power to Congress have been interpreted to impose limits on the legislative capacity of the states. Most prominently, the grant of power to Congress to regulate commerce "among the several states" is understood to preclude some kinds of state action that represent an impediment to, or a discrimination against, interstate commerce. The law of this "negative commerce power," of which we can give only a few examples, is complicated and obscure, casting a shadow over state lawmaking at least as imposing as that attached to the federal legislative power.

The federal division of power affects state law in another way. The constitutional scheme inevitably left open the possibility of overlapping state and federal legislative authority. Construction of a dam on a river might be both a matter of interstate commercial navigation and of health and safety. Like just about every other federal system, the United States Constitution resolves any conflicts of legislation by according supremacy to the national regulation. ${ }^{48}$ The extraordinary expansion of the scope of federal legislative activity already noted, has substantially extended the area of possible conflict. The degree to which this has imposed a federal constitutional dimension on the creation and application of state law is, perhaps, greater than a mere statement of the rule might suggest. The decision as to the existence and extent of a conflict with federal law is not a simple matter of a comparison of two texts. The Supreme Court has recognized that the federal "preemption" of state law may be express or implied. It has held moreover that state law may be impliedly preempted where, among other things, "the scheme of federal regulation is so pervasive as to make reasonable the inference that Congress left no room for the states to supplement it" and "where state law stands as an obstacle to the accomplishment and execution of the full pur-

46. Id. at 566 .

47. Id. quoting Marbury v. Madison, 5 U.S. (1 Cranch) 137, 177 (1803).

48. Art. VI para. 2. 
poses and objectives of Congress." 49 Consequently, there now exists a body of judicially defined doctrine which, while nominally a mere inquiry into the extent of Congressional regulation, in fact imposes a set of constitutional standards on any state law arguably impinging a subject of federal regulation. ${ }^{50}$

Moreover, under the modern liberal view of the permissible scope of federal legislation, Congress has ventured well into the traditional governmental concerns of the state. For example, the enactment of a massive federal law of environmental protection in the past thirty years has put in question the constitutional validity of a great deal of common law and legislation emanating from the states' core authority to protect the health and welfare of their citizens. ${ }^{51}$ National energy legislation dealing with conservation and safety matters has given rise to a significant amount of litigation challenging overlapping state law. ${ }^{52}$ The relatively recent federal regulation of employee benefit plans has raised questions about the validity of state law in wide and varied fields including wages and hours, marital and inheritance rights, even the state taxation of medical facilities. ${ }^{53}$

In all of these cases, of course, the formal role of constitutional rules stems from the simple and undisputed recognition of the priority of federal law, In practice, however, the adjudication of the validity of state law turns on more than a mere inspection of the meaning of the federal act in question. Necessarily that inquiry is informed by an understanding of the relative roles of states and federal government in the constitutional system. This includes a consideration of the importance, in different contexts, of the deference due to states in the exercise of their traditional functions ${ }^{54}$ as well as the intensity of the federal interest in a particular subject. ${ }^{55}$ Thus the large themes of constitutional federalism become a critical element in determining the content of wider spheres of law.

49. Gade v. National Solid Waste Management Association, 505 U.S. 88, 98 (1992).

50. See generally Chermerinsky, supra n. 5, at 284-306.

51. See Strasser, "Environmental Law in the United States Federal System," 9 Conn. J. Int'l L. 719 (1994).

52. See, e.g., Pacific Gas \& Elec. v. State Energy Resources Conservation of Development Commission, 389 U.S. 235 (1967); Silkwood v. Kerr-McGee, 464 U.S. 238 (1984).

53. Employee Retirement Income Security Act of 1974. 29 U.S.C. $\& 1001$ et seq. (1994). See, e.g. DeBuono v. NYSA-ILA Med. \& Clin. Services Fund, 138 L. Ed. 2d 21, n. 1 (1997); California Div. of Labor Standards Enforcement v. Dillingham Contsr. N.A., 117 S. Ct. 832 (1997); Boggs v. Boggs, 138 L. Ed. 2d 45 (1997).

54. See Rice v Santa Fe Elevator Corp., 331 U.S. 218, 230 (1947).

55. See Pennsylvania v. Nelson, 350 U.S. 497, 504 (1956). 


\section{The Constitutionalization of Procedure}

\section{Criminal Procedure}

Probably the best known and most thorough constitutionalization of American law, indeed one which has served as a model in many respects for international human rights agreements and development in other countries, is to be found in the rules of criminal procedure. The federal constitution itself, in the original document and in the Bill of Rights which went into effect in 1791, contains an extensive catalogue of more or less specific rules of criminal procedure (see art. I $\$ 9$ para. 2; art. III $\$ 2$ para. 3 ; art. III $§ 3$; art. IV $\$ 2$ para. $2 ; 4^{\text {th }}$, $5^{\text {th }}, 6^{\text {th }}$, and $8^{\text {th }}$ Amendments). In addition, the broad principle of "due process of law" is enshrined in the $5^{\text {th }}$ Amendment, and has served as the vehicle for some additional guarantees.

These provisions are important enough in their original role as limitations on federal courts and prosecutors in criminal cases, especially in view of the expansion of federal regulatory laws mentioned above. More important still for our theme of constitutionalization, however, is the applicability of most of these protections to the state criminal process, through the due process clause of the $14^{\text {th }}$ Amendment. ${ }^{56}$ While the Supreme Court has insisted that "due process" includes only those protections which are "of the very essence of ordered liberty," 57 in the 1960's it began to take an expansive view of what was "of the very essence" both for federal prosecutions and for purposes of "incorporation" into the $14^{\text {th }}$ Amendment. 58 More recently the Court has back-tracked a bit on both fronts (federal and state), and has indicated a willingness to accommodate some local variations in enforcement of incorporated protections. ${ }^{59}$ For example, the federal right to a jury trial applies to all but "petty" state criminal cases, ${ }^{60}$ but not its requirements that juries have 12 members $^{61}$ and render unanimous verdicts. ${ }^{62}$ Still the room for variation and experimentation in the criminal process at the state and local level remains much narrower than it once was, unless they give

56. It was said recently that "roughly $99 \%$ of all criminal prosecutions still are brought in the state systems." Wayne R. LaFave \& Jerold H. Israel, Criminal Procedure 46 ( $2 \mathrm{~d}$ ed. 1992).

57. Palko v. Connecticut, 302 U.S. 319, 325 (1937).

58. LaFave \& Israel, supra n. 56, at $73 \mathrm{ff}$., refer to this as "the preference for expansive interpretations."

59. North v. Russell, 427 U.S. 328 (1976); Shadwick v. Tampa, 407 U.S. 345 (1972).

60. Duncan v. Louisiana, 391 U.S. 145 (1968).

61. Williams v. Florida, 399 U.S. 78 (1970). Cf. Ballew v. Georgia, 435 U.S. 223 (1978) (5 is not enough).

62. Apodaca v. Oregon, 406 U.S. 404 (1972). Cf. Burch v. Louisiana, 441 U.S. 130 (1979) (6-member juries must be unanimous). 
greater protection to the criminal suspect/defendant than is required by the federal constitution. ${ }^{63}$

One of the "incorporated" constitutional rules which has the greatest potential for complicating criminal proceedings and increasing appeals is the so-called "exclusionary rule," which requires evidence obtained in violation of the defendant's constitutional rights to be excluded from the trial. This is not in the text but was developed by the Court early in this century as a remedy for violations by federal officials. ${ }^{64}$ Its incorporation into $14^{\text {th }}$ Amendment due process for application to the states in $1961^{65}$ greatly intensified criticism of its factual foundations and constitutional legitimacy, and eventually led to some retrenchment by the Court in the direction of a limited "good faith exception."66 In holding the rule inapplicable to certain special proceedings, ${ }^{67}$ the Court weighed the likelihood that exclusion would deter future violations by the officials involved, against the impairment that exclusion would impose on the effective functioning of the adjudicating body. This approach involves case-by-case factual analysis under rather fluid criteria, increasing uncertainty and thereby reinforcing constitutionalization in our sense of the term. In any event the pretrial "suppression hearing" has become a staple of criminal procedure. 68

Other expansive "remedial" interpretations of constitutional protections can be seen as having similar effects. The right to the assistance ${ }^{69}$ of counsel has been held to require, on pain of reversal of any conviction affected by its violation, not only that the state provide counsel at its expense to defendants who can't afford their own ${ }^{70}$ and are at risk of incarceration, ${ }^{71}$ but also that counsel perform with at

63. See LaFave \& Israel, supra n. $56, \S 2.10$.

64. Weeks v. United States, 232 U.S. 383 (1914). The Court stated then that without exclusion of the evidence the $4^{\text {th }}$ Amendment protection "is of no value, and ... might as well be stricken from the Constitution", id. at 393. For a trenchant critique of the Court's thinking on this issue in these early cases, with many further references to the more recent debate over the legitimacy of the rule, see Akhil Amar, The Constitution and Criminal Procedure: First Principles 22 ff. (1997).

65. Mapp v. Ohio, 367 U.S. 643 (1961), overruling Wolf v. Colorado, 338 U.S. 25 (1949).

66. For discussion see LaFave and Israel, supra n. 56, at 107-13.

67. Costello v. United States, 350 U.S. 359 (1956) (grand jury proceedings); One 1958 Plymouth Sedan v. Pennsylvania, 380 U.S. 693 (1965) (forfeiture of property unlawfully possessed); U.S. v. Janis, 428 U.S. 433 (1976) (proceedings to enforce federal tax lien); I.N.S. v. Lopez-Mendoza, 468 U.S. 1032 (1984) (deportation proceedings).

68. See LaFave \& Israel, supra n. $56, \$ 10.1$.

69. The defendant has a right of self-representation, Faretta v. California, 422 U.S. 806 (1975).

70. Johnson v. Zerbst, 304 U.S. 458 (1938), made applicable to the states by Gideon v. Wainwright, 372 U.S. 335 (1963), which overruled Betts v. Brady, 316 U.S. 455 (1942).

71. Argersinger v. Hamlin, 407 U.S. 25 (1972). 
least minimal competence ${ }^{72}$ and freedom from conflicts of interest. ${ }^{73}$ The privilege against self-incrimination has been held to require that a suspect be informed of his rights to counsel and to remain silent before any statement is taken from him while in official custody. ${ }^{74}$ All of these rulings involve subtle distinctions and case-by-case weighing of multiple factors, occasioning countless appeals and many Supreme Court decisions refining and confining their scope. While the constitution has not been found to imply a complete code of criminal procedure, as some had claimed, it has become and remains a major if not the most important source of law for the process.

\section{Civil Procedure}

The impact of the federal constitution on civil procedure has been considerably more circumscribed. Three issues will be noted here: the territorial competence of states courts in relation to nonresident parties; the right to a jury trial; and the right to notice and an opportunity to be heard.

The territorial competence of state courts in relation to non-resident parties is regulated in the first instance by state law, but limited by the due process clause of the $14^{\text {th }}$ Amendment. (This is in some ways another aspect of the constitutional federal allocation of powers discussed above.) For the normal case of a nonresident defendant the Court has settled on a flexible "minimum contacts" standard which requires a showing that the defendant have engaged in activities which constitute a purposeful availing of the privileges and benefits of the law of the forum state. ${ }^{75}$ Recent cases have set outer limits for state courts, ${ }^{76}$ not only by finding otherwise relevant contacts with a particular state to be fortuitous and insubstantial, but also by striking down the use of a traditional Anglo-American basis of territorial competence ("quasi in rem jurisdiction") founded on the ownership by the defendant of property within the forum state or district, and holding instead that the general standard was applicable. ${ }^{77}$ On the other hand it unanimously sustained another traditional Anglo-American "exorbitant" basis of jurisdiction, that based on actual service of pro-

72. Strickland v. Washington, 466 U.S. 668 (1984).

73. Wheat v. U.S., 486 U.S. 153 (1988).

74. Miranda v. Arizona, 384 U.S. 436 (1966).

75. International Shoe Co. v. Washington, 326 U.S. 310, 316 (1945); Hanson v. Denckla, 357 U.S. 235, 253 (1958).

76. Kulko v. Superior Court, 436 U.S. 84 (1978) (owing child support to children who moved to the forum statewith their mother since the obligation was established, insufficient to sustain jurisdiction to increase the support obligation); World-Wide Volkswagen Corp. v. Woodson, 444 U.S. 286 (1980) (auto dealer and distributor operating exclusively in New York and the New York metropolitan region, respectively, not subject to suit in Oklahoma where a car they sold in New York happened to have been driven and suffered a breakdown).

77. Shaffer v. Heitner, 433 U.S. 186 (1977); Rush v. Savchuk, 444 U.S. 320 (1980). 
cess within the state ("transient jurisdiction"), despite the fact that the defendant's presence within the state at the time of service was of brief duration and had no connection with the dispute that was the subject matter of the action. ${ }^{78}$ It also held that the general standard does not apply to persons made members of a plaintiff class in a class action proceeding without their consent and without any of the usually necessary contacts with the forum state, so long as they are given notice and an opportunity to withdraw from the class. ${ }^{79}$ Within these rather flexible parameters, there is much room for uncertainty and dispute in particular cases.

The right to a jury trial in civil cases is guaranteed by the $7^{\text {th }}$ Amendment for federal courts. Although that right has not been incorporated into the due process clause of the $14^{\text {th }}$ Amendment so as to be applicable as such to the states, ${ }^{80}$ almost all states have comparable provisions in their own constitutions, so that one can say that the right to a jury trial has been constitutionalized generally, and that it significantly limits the ability of state and federal legislatures to adopt procedural reforms aimed at making civil litigation more efficient and less costly. The right is not applicable to all civil cases, however, but limited in most jurisdictions which recognize it to cases which would have been tried in courts of law in the bifurcated English system of law courts and equity courts as it existed at the time at which the particular constitutional guarantee was adopted (the "historical test").81 This historical test has considerable uncertainties in systems virtually all of which abandoned the bifurcated court system long ago, and it seems particularly problematical for mixed claims and of new causes of action not recognized at the time of adoption of the constitutional guarantee. It has been heavily criticized in the literature, ${ }^{82}$ but the Supreme Court shows no signs of abandoning it for the federal courts. ${ }^{83}$ The essential elements of the federal approach are (i) for mixed equitable and legal cases, to insist on trial of the legal issues to a jury before deciding the equitable ones, ${ }^{84}$ (ii) for new, especially statutory claims not known at the time of adoption of the constitutional provision, in the absence of Congressional direction, to find the closest analogy to the new claim in the catalogue of claims originally recognized and to treat the new claim the same way, ${ }^{85}$ and (iii) for statutory claims involving private rights where

78. Burnham v. Superior Court, 495 U.S. 604 (1990).

79. Phillips Petroleum Co. v. Shutts, 472 U.S. 797 (1985).

80. Minneapolis, St. Louis R.R. Co. v. Bombolis, 241 U.S. 211 (1916).

81. See Jack H. Friedenthal, Mary Kay Kane \& Arthur R. Miller, Civil Procedure $\S \S 11.3,11.7$ (2d ed. 1993).

82. See Friedenthal, Kane \& Miller, supra, at 490 , with further references.

83. See, most recently, Teamsters Local 319 v. Terry, 494 U.S. 558 (1990).

84. Beacon Theatres, Inc. v. Westover, 359 U.S. 500 (1959); Dairy Queen, Inc. v. Wood, 369 U.S. 469 (1962).

85. Beacon Theatres, Inc., supra; Friedenthal, Kane \& Miller, supra n. 81 at 500. 
Congress has specifically excluded jury trial, to determine whether the statutory claim is truly new or only a reclassification of a traditional claim, and in the latter case to sustain the right to jury trial. ${ }^{86}$

In terms of the procedure itself, the minimum required by the due process clause of any governmental decision-making agency, whether judicial or administrative, when taking action which will "deprive" a specific person of "life, liberty or property," is notice to that person and an opportunity to be heard. ${ }^{87}$ The Court has held notice ("service of process") by publication in a local newspaper invalid, where alternatives are practicable which are "reasonably calculated, under all the circumstances, to apprise interested parties of the pendency of the action and afford them an opportunity to express their objections." 88 It also held that prior notice and hearing were required for pre-judgment seizure (to preserve it for payment of eventual judgment) of two categories of property belonging to the defendant: wages 89 and property which is the subject-matter of the plaintiff's claim ("replevin").90 The Court has also held, however, that the right to such notice and hearing may be waived by private agreement between the parties. ${ }^{91}$ It is difficult to assess the current impact of these decisions, and to the extent that they have shifted the power to provide for expedited procedures from the public to the private sphere they may be said to have resulted in a reduction in constitutionalization as we have used the term. But insofar as the private authority so created is itself defined by somewhat obscure constitutional criteria subject to elaboration and refinement in future constitutional litigation, it may also be seen as the extension of constitutional rule to matters previously governed by ordinary statute and common law.

\section{Constitutional Rules and Private Conduct}

The constitutionalizing effect of the determination to treat the Constitution as supreme law has mainly been confined to one kind of law, that relating to the decisions and activities of the state in all of its manifestations. The Constitution is, on its face, a law for the state. There are, to be sure, some provisions that do not refer specifically to government, including many of the provisions of the first ten

86. Granfinanciera, S.A. v. Nordberg, 492 U.S. 33 (1989).

87. For elaboration on the issues presented by this core requirement, see, e.g., the discussion in Chermerinsky, supra n. 5, at 448-70.

88. Mullane v. Central Hanover Bank \& Trust Co., 339 U.S. 306 (1950).

89. Sniadach v. Family Finance Corp., 395 U.S. 337 (1969).

90. Fuentes v. Shevin, 407 U.S. 67 (1972). Cf. Mitchell v. W.T. Grant \& Co., 416 U.S. 600 (1974), and North Georgia Finishing, Inc. v. DiChem, Inc. 419 U.S. 601 (1975), allowing seizure subject to a subsequent procedure initiated by the defendant at which the plaintiff must prove his right to seize.

91. D.H. Overmyer v. Frick, 405 U.S. 174 (1972). Cf. Swarb v. Lenox, 405 U.S. 191 (1972), providing limited protection against waiver for weaker parties. 
amendments, the Bill of Rights. But the kind of limitations expressed, as well as the textual and historical context, make the same understanding evident. There are some exceptions. The now repealed Eighteenth Amendment prohibited the "manufacture, sale or transportation of intoxicating liquors" and was, thus, a direct regulation of the conduct of private individuals. The Thirteenth Amendment declaring that "neither slavery nor involuntary servitude. . . shall exist within the United States" was early declared to be "undoubtedly self-executing without any ancillary legislation,"92 indicating that it directly controlled private relations. In fact, however, the substantial impact of the amendment has been felt principally through the Congressional enforcement legislation that it authorized. ${ }^{93}$ Apart from these exceptional cases, the Constitution appears to be concerned only with exercise of public authority.

Of course, the political judgments implicit in the rules of the Constitution may exert an influence on the law governing private activity. In contrast to some European legal systems, the American Constitution has no formal, juridical drittwirkung, imposing its values on the interpretation of private law rules. ${ }^{94}$ Still, the Constitution affects the lawmaking process. The Constitution prohibits government discrimination or segregation on the basis of race and this principle, especially as elaborated in the judgments of the courts, has undoubtedly influenced the enactment and content of statutes, state and federal, prohibiting parallel actions by private individuals. ${ }^{95}$ Modern labor legislation has been characterized as an attempt to bring constitutional principles of freedom of expression and association to the relationship among, employers, unions and workers. ${ }^{96}$

Common law adjudication may also be constitutionalized to the extent that the judges have molded their decisions in light of constitutional values. The relationship of individuals to professional associations has been regulated by common law decisions explicitly borrowing from constitutional doctrine defining the "due process of law" demanded of public institutions. ${ }^{97}$ The developing constitutional right of privacy and personal autonomy has also found expres-

92. The Civil Rights Cases, 109 U.S. 3, 20 (1883).

93. See, e.g., Jones v. Alfred Mayer Co., 392 U.S. 409 (1968).

94. Cf. David P. Currie, The Constitution of the Federal Republic of Germany 18285 (1994).

95. See 1 Rodney A. Smolla, Federal Civil Rights Acts $\& 1.01$ [1] at 1-3 (3d ed. 1994).

96. See Summers, "The Privatization of Personal Freedoms and Enrichment of Democracy: Some Lessons from Labor Law," 1986 U. Ill. L. Rev. 689. On the interaction of constitutional doctrine and legislation see generally Lupu, "Statutes Revolving in Constitutional Law Orbits," 79 Va. L. Rev. 1 (1993).

97. See Ascherman v. St. Francis Mem. Hosp., 45 Cal. App. 3d 507, 512, 119 Cal. Rep. 507, 510 (Ct. App., 1975). 
sion in a common law right to refuse medical treatment. ${ }^{98}$ Numerous common law rules require some judicial estimation of "public policy" and, not unnaturally, constitutional values have often been looked to as a guide to such policy. The ordinarily almost unrestricted right of a private employer to discharge an employee-at-will, for example, has been held subject to an exception for terminations on the basis of race or gender, a policy which, as already noted, cannot be separated from the modern judicial elaboration of the constitutional requirement of "equal protection of the laws."99

Of its own force, on the other hand, the Constitution (except in the very narrow cases mentioned) consistently has been held to apply to governmental actors, not to the relations among private persons. This distinction between constitutionally governed public acts and constitutionally immune private conduct has not only been recognized but endorsed by the Supreme Court as an "essential dichotomy."100 This limitation effectively leaves the great mass of human activity to the particular, flexible and democratically determined process of ordinary lawmaking. Importantly, it also allows most of those decisions to be made on a state level rather through the centralized and almost irreversible device of federal constitutional pronouncement. ${ }^{101}$

Nevertheless, the courts have sometimes applied the rules of the Constitution to ostensibly private action by treating it as action of the state. Two large and overlapping categories have been identified where this characterization is proper. In the first the private action is one in which the government somehow participates. For example, the refusal of service to African-Americans by a private restaurant was held to be an unconstitutional denial of the "equal protection of the laws" because the restaurant was a tenant in a parking structure owned, operated and maintained by the state. Given this "symbiotic relationship,"102 the Supreme Court concluded that the state had "insinuated itself into a position of interdependence" with its offending tenant becoming a "joint participant" in the discrimination. ${ }^{103}$ The Court has never satisfactorily defined the degree of state involvement that suffices to make private action amenable to constitutional constraint and its subsequent decisions have been slow to find state responsibility where the state's interest is other than proprietary.

98. See Fosmire v. Nicoleau, 551 N.E. 2d 77, 80-84 (N.Y. Ct. App. 1990) (applying state constitutional doctrine).

99. See Lockhart v. Commonwealth Educ. Systems Corp., 439 S.E.2d 328, 330-32 (Va. Sup. Ct. 1994).

100. Moose Lodge No. 107 v. Irvis, 407 U.S. 163, 172 (1972).

101. See Lugar v. Edmondson, 457 U.S. 922,936 (1982).

102. This phrase was used to describe the situation in Burton in later cases. See., e.g., Moose Lodge No. 107 v. Irvis, 407 U.S. 163, 175 (1972).

103. Burton v. Wilmington Parking Authority, 365 U.S. 715, 725 (1961). 
Thus neither public funding, nor licensing, nor extensive regulation have been held enough to create state action. ${ }^{104}$

Secondly, private entities exercising functions traditionally associated with the state have sometimes been held directly subject to the restrictions of the Constitution. When a privately owned "company town" prohibited the distribution of religious literature, the Supreme Court held that the state could not prosecute violators of this policy under the trespass laws. ${ }^{105}$ Effectively this was a holding that the private company was subject to the duty of the state not to restrict free expression and religious exercise. The town was open to the public and was, in all apparent ways, indistinguishable from an ordinary municipality. The Court has employed a similar "public function" rationale in holding that a private group that effectively controls the selection of a party's candidates for public office may not discriminate on the basis of race. ${ }^{106}$ Like the criterion of state involvement, however, the amount of "publicness" of an activity necessary to subject it to constitutional rules has not been defined with precision. The procedures followed in operating a private school and in effecting, without the aid of a public officer, the seizure of a debtor's property have been held not to involve public functions and thus to be free of the constitutional requirements of "due process."107

These definitional difficulties indicate the protean potential of any expansion of the reach of the reach of the Constitution beyond plainly official conduct. After all, all private rights depend on the fact that they may, in the last resort, be enforced by the agencies of the law, and especially the courts. In Shelley v. Kraemer ${ }^{108}$ the Supreme Court held that the judicial enforcement of a real estate covenant prohibiting the sale of a property to non-whites violated the equal protection clause of the Fourteenth Amendment. With little attention to the more general implications of its decision, it held that, since the actions of courts were obviously actions of the state, a judgment effecting a privately intended, racially discriminatory result was unconstitutional. It was unmoved by the fact that the official

104. See, e.g., Rendell-Baker v. Kohn, 457 U.S. 830 (1982) (funding); Moose Lodge No. 107 v. Irvis, 407 U.S. 163 (1972) (licensing); Jackson v. Metropolitan Edison Co., 419 U.S. 345 (1974) (regulation). Compare Lebron v. National Railroad Passenger Corp., 513 U.S. 374 (1995), (finding government chartering and participation in management of a corporation rendered its activities state action.)

105. Marsh v. Alabama, 326 U.S. 501 (1946).

106. Terry v. Adams, 345 U.S. 461,470 (1953). The history of constitutional litigation concerning the nomination process of the Texas Democratic party provides a particularly good example of the intentional substitution of private for public institutions for the purpose of avoiding constitutional limitations on the state. See Chemerinsky, supra n. 5, at 401-02.

107. Rendell-Baker v. Kohn, 457 U.S. 830 , 837-43 (1982)(school); Flagg Brothers v. Brooks, 436 U.S. 149, 157-63 (1978) (seizure and sale of property).

108. 374 U.S. 1 (1947). 
rules and policies pursuant to which the court acted were themselves racially neutral. ${ }^{109}$

It is clear that an unrestrained embrace of this rationale would mean the Constitution could apply directly to almost every kind of private decision. The refusal, on racial grounds, to invite guests to a private home, the removal of protesters from a private office, and the termination of a private employee without advance notice and hearing would all raise constitutional questions. Each of these private decisions might be vindicated by judicial enforcement and, therefore, even their successful non-judicial assertion may be said to depend on the express or implied threat of such recourse. The holding in Shelley exemplifies the emptiness of both of the judicial criteria for finding the minimum public presence necessary to trigger the application of the Constitution. The state is a silent, but critical, participant in every assertion of a private right. Similarly, every private actor relying on a private right may be seen as wielding the power of the state in the sense that he may count on the state to back him up in the case of resistance. It is, perhaps, a recognition of this potential that explains why Shelley has produced so few successors. In fact, when private property owners made use of the considerably more state-like power of the criminal trespass laws on a racially discriminatory basis, a majority of the Supreme Court took pains to decide the case on other grounds. ${ }^{110}$

More generally, one may doubt whether it is possible to identify some intrinsic quality that makes an action "public" as opposed to merely identifying some specific, historically defined, manifestations of public power. If the Constitution governs every action which may properly be described as an exercise of state authority, it governs, as the discussion here has indicated, everything. In the past thirty years a widespread academic critique of the state action doctrine has been based on a powerful deconstruction of the public-private distinction. All social activity takes place in a publicly defined context. The state defines, by action or inaction, the very context and categories in which all private relations exist. Every sale, for example, presumes a law of property and contract which are, ultimately, the expressions of state policy. Indeed, the very recognition of the natural human being (not to mention the corporation) as a rights-bearing, legally compe-

109. "Nor is the Amendment ineffective simply because the particular pattern of discrimination which the State has enforced, was defined initially by the terms of a private agreement." Id. at 20. "Rather these are cases in which the States have made available to such individuals the full coercive powers of government to deny to petitioners on the grounds of race or color, the enjoyment of property rights. . " Id. at 19.

110. See Bell v. Maryland, 378 U.S. 226, 228 (1964). 
tent agent is attributable to both explicit and implicit state decisions. ${ }^{111}$

The broad juridical criteria created in the state action jurisprudence of the Supreme Court, therefore, have failed to define a limited concept of public authority subject to constitutional regulation and the extent of constitutionalization remains undefined. It ebbs and flows with the particular preferences of the changing membership of the Court, leading to a situation which, as the Court itself continues to acknowledge, has "not been a model of consistency." 112

\section{The Consequences of Constitutionalization}

\section{A. The Problem of Remedies}

Among the practical consequences for which the Supreme Court's interpretive work has been criticized most vehemently is one that is not unique to constitutional cases, although these can be particularly difficult examples. Much has been said about the propriety or impropriety of a court essentially taking significant supervisory control of the continuing operation of a public institution such as a school system or a prison, in order to assure compliance with legal or constitutional mandates. Probably the most spectacular examples of this in the constitutional sphere have occurred in attempting to enforce the desegregation of public schools, often against massive resistance, ${ }^{113}$ after the landmark ruling of Brown v. Board of Education finally made state-enforced separation of the races unlawful. In numerous cases decided since that decision the Supreme Court has established that the sufficiency of any remedial response is itself a matter of constitutional law. The result has often been long-term and detailed judicial supervision of the operation of the formerly segregated systems.

Remedial issues have included not only pupil assignment but also distribution and recruitment of minority faculty, organization of extracurricular activities, location of new schools in relation to typically segregated housing patterns, and distribution of funds and facilities among schools in relation to racial composition. ${ }^{114}$ The typical pattern has been for the court to require the school system's governing body to present a plan for achieving desegregation, and if it

111. See Kay, "The State Action, Doctrine, the Public-Private Distinction and the Independence of Constitutional Law," 10 Const. Comm. 329, 334-37 (1993) and authorities cited.

112. Lebron v. National R.R. Passenger Corp., 513 U.S. 374, 378 (1995) quoting

Edmondson v. Leesville Concrete Co., 500 U.S. 614,632 (1991).

113. See, e.g., Chermerinsky, supra n. 5, at $576 \mathrm{ff}$.

114. See, e.g., Green v. County School Board, 391 U.S. 430, 435 (1968). The Court held that a plan simply allowing each child to choose which school to go to, resulting in no significant actual change, was insufficient. 
does not submit a satisfactory one for the court itself to order one. ${ }^{115}$ The court then retains jurisdiction until "all vestiges of state-imposed segregation" have been eliminated. ${ }^{116}$

Two relatively early decisions established important constitutional limitations on remedial decrees. First it held that a remedy involving multiple school districts as separate governmental entities (as in a city district surrounded by numerous suburbs) is not permissible unless each is shown to have been guilty of intentional segregation, even if, because of "white flight" to the suburbs, a remedy desegregating the city alone would be inadequate. ${ }^{117}$ Second, it held that where a school system had implemented a desegregation plan which achieved appropriate racial balance in all schools, it could not be required to readjust the attendance patterns annually so as to maintain that situation, so long as subsequent changes in attendance patterns did not result from any intentional segregative action on the part of the school system. ${ }^{118}$

The trend of recent decisions has been to qualify the most sweeping remedial orders, but also to ensure that termination of judicial supervision because the district has achieved desegregation be done with caution. In 1991 the Court held that such a termination could only be based on carefully elaborated findings not only that the district has complied in good faith with the decree but also that current segregation in housing patterns, which make mandatory pupil reassignment necessary in order to avoid actual separation in the neighborhood schools, is not itself a "vestige" of prior school segregation.119 The district could not be required to counteract housing segregation as such, because these supervisory remedies were intended only to be temporary measures to remedy past school discrimination rather than "judicial tutelage for the indefinite future."120

The most recent decisions in this area, involving the school system of Kansas City, Missouri, seem particularly to reflect judicial frustration at the intractability of the problems of desegregation. After unusually extended litigation against the city school system and the state (which had required segregation by constitution and statute until after Brown), from which suburban districts were dropped, the lower court found violation and accepted a proposed "magnet school" plan designed to attract voluntary transfers by suburban children as well as to enhance urban pupils' performance. The plan would have

115. Green, supra; Swann v. Charlotte-Mecklenburg Board of Education, 402 U.S. 1 (1971).

116. Swann, supra, 402 U.S. at 15.

117. Milliken v. Bradley, 418 U.S. 717 (1974).

118. Pasadena City Board of Education v. Spangler, 427 U.S. 424 (1976).

119. Board of Education of Oklahoma City Public Schools v. Dowell, 498 U.S. 237 (1991).

120. Dowell, supra, 498 U.S. at 249. 
cost $\$ 450$ million in capital improvements, salary increases and other programs, and the order imposed $75 \%$ of these costs on the state while leaving $25 \%$ with the city system (the latter's share to be financed through tax increases). ${ }^{121}$ Several years after the plan went into effect the Court held that it impermissibly pursued two goals unrelated to remedying intentional segregation within the system: (i) the funding of salary increases for faculty and staff designed to attract high-quality personnel and students from outside the system, where the evidence did not show that the city system's segregation substantially affected suburban racial composition; and (ii) use of an improvement in pupil test scores to the national average as a measure of when the remedial program would achieve its purpose. ${ }^{122}$ To be sure, this was a program proposed by the city system itself, while the state more or less successfully portrayed itself as a pocketbook of convenience for the system's unrealistic ambitions, but it has become for many a symbol of the failure of judicial remediation rather than an isolated reductio ad absurdum of an otherwise valid endeavor. In either case it provides an unusually dramatic example of the extent to which courts, acting under the authority of the Constitution, may sometimes feel justified in substituting their own decisions for those of the officials ordinarily entrusted with the operation of public institutions.

\section{B. The Problem of Judicialization}

The examples just provided of the tendency, in some circumstances, for judges to progress from authoritative exposition of the Constitution to active design and administration of constitutionally based remedies, illustrate an important consequence of the constitutionalization of the American legal system. The amount of "constitutionalization" cannot be determined by merely noting that it calls for the application of the rules of the constitutional text to all other lawmakers and law-appliers. The practical impact of treating the Constitution as supreme law may be either limited or far-reaching depending on the effective content of the Constitution. And that content may not be fixed, but may expand and contract depending on the meaning the Constitution has for its authoritative interpreters. Although the direction of change has been far from uniform, our report has surveyed the ways in which the understanding of the reach of the Constitution has been enlarged. Where this is so, the Constitution has either displaced or modified the application of law emanating from other sources, federal and state legislatures, executive agencies, or administrative bodies.

121. The order to increase taxes was approved in Missouri v. Jenkins, 495 U.S. 33 (1990).

122. Missouri v. Jenkins, 510 U.S. 70 (1995). 
Certain generalizations may be ventured about the effect of this kind of change on the legal system. Perhaps the most important derives from the manner in which the increasingly decisive constitutional law is made. Ordinary subconstitutional law in the American legal system is principally the product of legislation, although judgemade common law still governs important aspects of legal relations. With the exception of the common law, which is itself subordinated to enacted law, the process of ordinary lawmaking exhibits certain important characteristics. It is prospective and rational and it usually draws its solutions to the issues at hand from fairly well-defined estimates of public policy, informed by a healthy regard for public opinion.

The process by which constitutional law is brought to bear on controversies is rather different. Constitutional rules, of course, are not just "applied:" they must first be "interpreted" and, as the examples already given show, the historical practice of constitutional interpretation in the United States has been, to say the least, creative. ${ }^{123}$ The experience of constitutional law has thus been an experience of law-making, but that constitutional law-making shares little with subconstitutional law-making. Crucially, constitutional law-making occurs in the course of litigation. Consequently, the order of and occasions for law-making are not defined by an evaluation of public need, but by the initiation of lawsuits by individual litigants. (The reference of constitutional questions to the Supreme Court by public officials is rare in state constitutional systems and actually unconstitutional in the federal system.) ${ }^{124}$ The agenda of constitutional law-making is thus, in some ways, a matter of happenstance. ${ }^{125} \mathrm{Un}$ like political lawmakers who are unfettered in their inquiry into the relevant facts and in seeking out competing arguments, the first and most influential sources for courts are the record of evidence and argument presented to them by opposing parties whose interests may not give a faithful representation of the full range of pertinent material. ${ }^{126}$ Perhaps most prominently, the process of constitutional lawmaking is designedly immune from the need to accommodate popular

123. See generally Fisch \& Kay, supra n. 1.

124. See John E. Nowak \& Ronald D. Rotunda, Constitutional Law $\$ 2.12$ (b), at 54 (4th ed. 1991) (federal); Comment, "The State Advisory Opinion in Perspective," 44 Fordham L. Rev. 81 (1975) (state).

125. The Supreme Court does exercise some control over its own docket, and in deciding what cases to hear, it does give consideration to the public importance of the constitutional questions presented. Stern et al., Supreme Court Practice \$4.11, at 184 (7th ed. 1993). But this is a negative power only.

126. These are not the exclusive sources of judicial information. The amicus curiae brief may expand the range of arguments considered. With respect to underlying social facts a court is entitled to do its own research but the capacity of a judge and even a staff of law clerks is not to be compared to the resources available to a legislature. See McCormack, "Property and Liberty- Institutional Competence and the Functions of Rights," 51 Wash. \& Lee L. Rev. 1, 1-2, 45-47 (1994). 
opinion. The decision to shield judges from democratic accountability was premised on the assumption that they were to be law-appliers, not law-makers. ${ }^{127}$ But for the topic of this report, namely the constitutional law created by the judges, the implications and merits of their apolitical status may be very different. ${ }^{128}$

For these reasons or others, the kind of law that has issued from the United States Supreme Court in the name of the Constitution is, in many respects, qualitatively different from that produced by more conventional legislators. One instance is particularly salient here. A principal technique of creative constitutional interpretation is the deduction of constitutional norms dealing with specific questions from the very broad injunctions of the Constitution. But, much more than seems to be the case with legislative law, even these deductions are phrased in broad formulas that, by themselves, give scant indication of how they will resolve particular future controversies. Take, as an example, the power to legislate in ways that restrict expression used for commercial purposes. The text of the First Amendment from which this law is inferred merely prohibits making a law "abridging the freedom of speech." After a series of adjudications grappling with this question, the Supreme Court arrived at a statement of the constitutional limitation as applied to "commercial speech" in the following terms:

For commercial speech to come within [the prohibition of] the First Amendment, it at least must concern lawful activity and not be misleading. Next we ask whether the asserted governmental interest [in limiting the speech] is substantial. If both queries yield positive answers, we must determine whether the regulation directly advances the governmental interest asserted and whether it is not more extensive than necessary to serve that interest. ${ }^{129}$

As might be expected, this pronouncement did not exactly end doubts about the permissible extent of public regulation of commercial speech. ${ }^{130}$ The subsequent judgments and resulting doctrine are characterized mainly by shifting majorities and fine distinctions,

127. See Hamilton, The Federalist No. 78, 469-71 (Clinton Rossiter, ed. 1961)

128. The classic statement of this issue in American constitutional writing is Alexander Bickel, The Least Dangerous Branch: The Supreme Court at the Bar of Politics 16-23 (1962). The politically protected role of American constitutional judges, given the realties of modern constitutional interpretation, has been justified by academic writers on a number of grounds. A good recent discussion is Michael J. Perry, The Constitution in the Courts: Law or Politics, 106-16 (1994).

129. Central Hudson Gas \& Elec. v. Public Service Commission, 447 U.S. 557, 566 (1980).

130. This is not even to mention the difficulty of being able to identify "commercial speech" in the first place. See Shiffrin, "The First Amendment and Economic Regulation: Away From A General Theory of the First Amendment," 78 Nw. U. L. Rev. 1212, 1228-32 (1983). 
holding, for example, that a state may not, in general, prohibit lawyers from sending solicitation letters to persons known to have particular legal problems, but it may prohibit sending such letters to accident victims in the thirty days following the event. ${ }^{131}$ It must be stressed that this model of constitutional-judicial lawmaking is far from unusual. The method of case by case extrapolation from openended, multi-factor "tests" is the staple of modern constitutional adjudication. ${ }^{132}$

To summarize, ordinary (subconstitutional) lawmaking, at least in its optimum form, is controlled by publicly accountable agencies acting on frankly political grounds through the promulgation of prospective, generally applicable and reasonably well-defined rules of conduct. Constitutional lawmaking is, in contrast, the domain of politically independent judges acting, usually retrospectively, on the basis of large principles of public morality, shaping those principles to different problems in an evolving and, necessarily, somewhat unpredictable manner. ${ }^{133}$ To be sure, the removal of certain important issues of human relationships from the sometimes short-sighted and venal arena of ordinary politics and their commitment to the decision of men and women whose principal concern is the design and application of the fundamental norms of a good society, is far from unattractive. ${ }^{134}$ But if the root purpose of constitutions is the imposition of the rule of law on the law-making process itself, the process of constitutionalization has, perhaps ironically, a subversive effect on constitutionalism. The subjection of more and more human activity to the ultimate control of the ad hoc, case-by-case judicial invocation of principle reduces the certainty and stability of law. Of course, the overall result of the establishment of constitutional judicial review in the American legal system can only be judged a remarkable advance in securing the rule of law. Still, the American experience also shows that the constitutionalization of law may increase the risk of what one early nineteenth century American jurist (criticizing a regime of legislative supremacy) described as

131. Compare Shapero v. Kentucky Bar Assoc., 486 U.S. 466 (1988) with Florida Bar v. Went For It, Inc., 515 U.S. 618 (1995).

132. See Robert Nagel, Constitutional Cultures: The Mentality and Consequences of Judicial Review 121-55 (1989).

133. Of course even the most conscientious of legislatures will frequently choose to formulate their laws in general terms, with the more or less explicit purpose of allowing the courts to fill in the details in the context of specific disputes in which the precise consequences of general rules can be more accurately gauged. This is done, however, against the acknowledged power of the legislature to review generally the interpretive work of the courts and to modify the laws where they have proved unsatisfactory in practice. It is precisely this corrective power that is made so much more difficult at the constitutional level.

134. See, e.g., Perry, supra n. 128; Dworkin, "The Forum of Principle," 56 N. Y. U. L. Rev. $469,516-18$ (1981). 
one great arbitration that would ingulph all courts of lawand [where] sovereign discretion would be the only rule of decision - a state of things equally favorable to lawyers and criminals. ${ }^{135}$

Looked at this way, constitutionalization is a mixed blessing.

135. Zephaniah Swift, A Vindication of the Calling of the Special Superior Court, at Middletown, on the 4th Tuesday of August, 1815, for the Trial of Peter Lung, Charged with the Crime of Murder 42 (1816). 